Evangelical Disenchantment 
This page intentionally left blank 


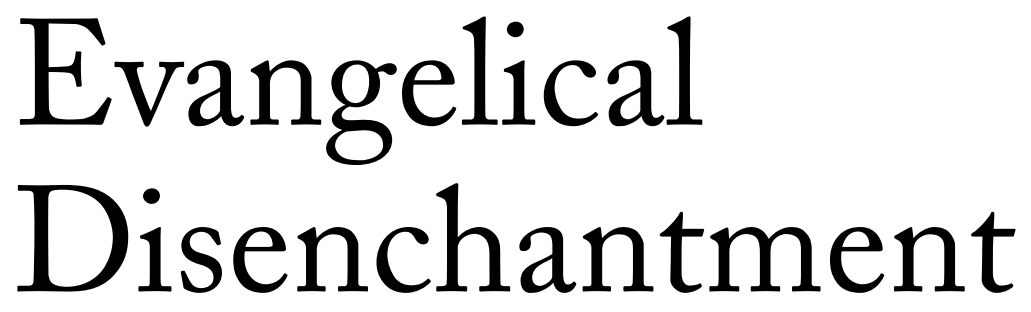

Nine Portraits of Faith and Doubt

\section{David Hempton}


Published with assistance from the Louis Stern Memorial Fund.

Copyright (C) 2008 by David Hempton.

All rights reserved.

This book may not be reproduced, in whole or in part, including illustrations, in any form (beyond that copying permitted by Sections 107 and 108 of the U.S. Copyright Law and except by reviewers for the public press), without written permission from the publishers.

Designed by Mary Valencia

Set in Adobe Caslon type by Integrated Publishing Solutions, Grand Rapids, Michigan

Printed in the United States of America by Vail-Ballou Press,

Binghamton, N.Y.

Library of Congress Cataloging-in-Publication Data

Hempton, David.

Evangelical disenchantment : nine portraits of faith and doubt /

David Hempton.

p. cm.

Includes bibliographical references and index.

ISBN 978-0-300-14067-5 (hardcover : alk. paper)

1. Religious biography. 2. Spiritual biography. 3. Evangelicalism.

I. Title.

BL72.H46 2008

270.8092'2-dc22

[B]

2008019003

A catalogue record for this book is available from the British Library.

This paper meets the requirements of ANSI/NISO Z39.48-1992 (Permanence of Paper).

It contains 30 percent postconsumer waste (PCW) and is certified by the Forest Stewardship Council (FSC).

$\begin{array}{llllllllll}10 & 9 & 8 & 7 & 6 & 5 & 4 & 3 & 2 & 1\end{array}$ 
For Louanne 
This page intentionally left blank 